\title{
Evoked Methane Photocatalytic Conversion to C2 Oxygenates over Ceria with Oxygen Vacancy
}

\author{
Jin Du ${ }^{1,2}$, Wei Chen ${ }^{2, *}$, Gangfeng $\mathrm{Wu}^{1,2}$, Yanfang Song ${ }^{2}$, Xiao Dong ${ }^{2}$, Guihua $\mathrm{Li}^{2}$, \\ Jianhui Fang ${ }^{1}$, Wei Wei ${ }^{2,3}$ and Yuhan Sun ${ }^{2,3, *}$ \\ 1 College of Sciences, Shanghai University, Shanghai 200444, China; dujin@sari.ac.cn (J.D.); \\ wugangfeng2018@sari.ac.cn (G.W.); jhfang@shu.edu.cn (J.F.) \\ 2 CAS Key Laboratory of Low-carbon Conversion Science and Engineering, Shanghai Advanced Research \\ Institute, Chinese Academy of Sciences, Shanghai 201210, China; songyf@sari.ac.cn (Y.S.); \\ dongx@sari.ac.cn (X.D.); liguihua@sari.ac.cn (G.L.); weiwei@sari.ac.cn (W.W.) \\ 3 School of Physical Science and Technology, ShanghaiTech University, Shanghai 201210, China \\ * Correspondence: chenw@sari.ac.cn (W.C.); sunyh@sari.ac.cn (Y.S.); Tel.: +86-21-20350954 (W.C.); \\ +86-21-20608005 (Y.S.); Fax: +86-21-20350867 (W.C. \& Y.S.)
}

Received: 27 December 2019; Accepted: 31 January 2020; Published: 6 February 2020

\begin{abstract}
Direct conversion of methane to its oxygenate derivatives remains highly attractive while challenging owing to the intrinsic chemical inertness of $\mathrm{CH}_{4}$. Photocatalysis arises as a promising green strategy which could stimulate water splitting to produce oxidative radicals for methane $\mathrm{C}-\mathrm{H}$ activation and subsequent $\mathrm{C}-\mathrm{C}$ coupling. However, synthesis of a photocatalyst with an appropriate capability of methane oxidation by water remains a challenge using an effective and viable approach.

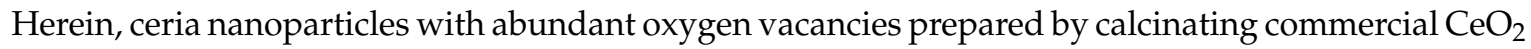
powder at high temperatures in argon are reported to capably produce ethanol and aldehyde from $\mathrm{CH}_{4}$ photocatalytic oxidation under ambient conditions. Although high-temperature calcinations lead to lower light adsorptions and increased band gaps to some extent, deficient $\mathrm{CeO}_{2}$ nanoparticles with oxygen vacancies and surface $\mathrm{Ce} \mathrm{e}^{\mathrm{III}}$ species are formed, which are crucial for methane photocatalytic conversion. The ceria catalyst as-calcinated at $1100{ }^{\circ} \mathrm{C}$ had the highest oxygen vacancy concentration and $\mathrm{Ce}$ III content, achieving an ethanol production rate of $11.4 \mu \mathrm{mol} \cdot \mathrm{g}_{\mathrm{cat}}{ }^{-1} \cdot \mathrm{h}^{-1}$ with a selectivity of $91.5 \%$. Additional experimental results suggested that the product aldehyde was from the oxidation of ethanol during the photocatalytic conversion of $\mathrm{CH}_{4}$.
\end{abstract}

Keywords: ceria; oxygen vacancy; photocatalysis; methane conversion

\section{Introduction}

Methane, as the main constituent of natural gas and shale gas, is widely used as an important and clean fuel [1]. With large-scale exploitation of unconventional natural gas, especially shale gas, direct conversion of methane as a chemical feedstock to valuable chemicals is highly attractive [2,3]. Nevertheless, the $\mathrm{CH}_{4}$ molecule exhibits a perfectly symmetrical tetrahedral structure with negligible electron affinity and the highest $\mathrm{C}-\mathrm{H}$ bond strength $\left(434 \pm 6 \mathrm{~kJ} \cdot \mathrm{mol}^{-1}\right)$ in all hydrocarbons, implying great difficulties in activating methane and breaking $\mathrm{C}-\mathrm{H}$ bonds [4-7]. To date, large-scale methane conversion applications are limited in thermal catalysis under harsh reaction conditions. For instance, methane reformation occurs at high temperature with complicated facilities [8,9], where methane is converted only to syngas $\left(\mathrm{CO} / \mathrm{H}_{2}\right)$ as a feedstock for the Fischer-Tropsch synthesis process $[10,11]$. Although oxidative coupling of methane can produce $\mathrm{C} 2$ hydrocarbons such as ethylene and ethane $[12,13]$, the existence of oxygen at high temperatures may present potential explosion risks and irreversible overoxidation to generate $\mathrm{CO}_{2}$ with low carbon utilization [14]. The highly promising 
non-oxidative coupling of methane to olefins and aromatics recently reported $[15,16]$ requires high temperatures $\left(\sim 1000{ }^{\circ} \mathrm{C}\right)$ to activate methane. It is highly desired to develop a new approach for methane conversion.

Using renewable solar energy to drive methane conversion by photocatalytic processes remains highly attractive, as they feature both solar energy storage and direct utilization of methane as feedstock. Moreover, water is the most naturally abundant source of oxidative species, which is available and low-cost for $\mathrm{CH}_{4}$ photooxidation [17]. Photocatalysis arises as a promising green strategy which could stimulate water splitting to produce oxidative radicals for methane $\mathrm{C}-\mathrm{H}$ activation and subsequent C-C coupling [17-20]. Synthesis of photocatalysts with appropriate capabilities of water splitting and methane oxidation remains a challenge under an effective and viable approach.

In the past few decades, cerium-based materials gained increasing attention as photocatalysts alternative to conventional titania, both for wastewater treatment [21-25] and water splitting [26-28]. As a representative cerium-based material, ceria is a wide-band-gap semiconductor (3.2-3.4 eV), which is used in various industrial applications such as solar energy for water splitting [29], as an oxygen storage material [30], and in solar cells, luminescent materials, and photocatalytic applications [31-33]. The usability of ceria for most of these applications depends on its ability to release or take up oxygen. Ceria has large oxygen storage capacity depending on $\mathrm{Ce}^{3+} / \mathrm{Ce}^{4+}$ redox cycles. More recently, some studies $[34,35]$ reported that increasing the surface defect concentration of ceria by calcination enhanced the photocatalytic degradation of dyes. The surface defects such as oxygen vacancies can promote the generation of hydroxyl radicals from water splitting under light irradiation. Based on this principle, modification of oxygen vacancy defects on ceria is theoretically beneficial for the photocatalytic oxidation of methane with water. Herein, we report commercially available ceria nanoparticles that behave inertly for methane photocatalytic conversion, which are then evoked and become active via high-temperature calcination in Ar atmosphere. Oxygen vacancies and surface Ce $\mathrm{C}^{\mathrm{III}}$ species in the as-prepared ceria catalysts are proposed to be crucial for generating oxidative radicals for methane oxidation under simulated solar light irradiation. The present study illustrates a simple and effective approach for fabricating active ceria catalysts for direct methane conversion and solar energy utilization fields.

\section{Results and Discussion}

\subsection{Characterizations of the Catalysts}

A series of ceria catalysts were synthesized by simple calcination of commercial $\mathrm{CeO}_{2}$ nanoparticles in $\mathrm{Ar}$ at $500-1100{ }^{\circ} \mathrm{C}$ (see Section 3.1 for details). The oxygen signal $(\mathrm{m} / \mathrm{z}=32$ ) from a temperature-programmed calcination indicated that lattice oxygen removal started around $600{ }^{\circ} \mathrm{C}$ (Figure S1A, Supplementary Materials), and the actual variation of the $\mathrm{CeO}_{2}$ crystal structure potentially occurred at lower temperature. The thermogravimetry (TG) curve of $\mathrm{CeO}_{2}$-raw (Figure S1B, Supplementary Materials) showed a very slow mass decrease until $580^{\circ} \mathrm{C}$, followed by rapid mass loss in the range of $580-1040^{\circ} \mathrm{C}$, implying lattice oxygen removal in Ar flow. The TG results further indicate that an inert atmosphere is more beneficial for oxygen removal to form oxygen vacancies, compared to the oxygen-rich atmosphere (Figure S1B, Supplementary Materials). At $500^{\circ} \mathrm{C}$ and higher temperatures with an interval of $100^{\circ} \mathrm{C}, \mathrm{CeO}_{2}$-x catalysts were obtained, where $\mathrm{x}$ represents the preserved calcination temperature. Figure 1 shows the typical photographs of as-prepared $\mathrm{CeO}_{2}-\mathrm{x}$ samples at different temperatures. The yellowish colors of $\mathrm{CeO}_{2}-500, \mathrm{CeO}_{2}-600$, and $\mathrm{CeO}_{2}-700$ seem highly similar to that of $\mathrm{CeO}_{2}$-raw. Apparent color darkening started from $\mathrm{CeO}_{2}-800$, and then gradually changed to brown with increasing calcination temperature. A possible reason may be derived from the variation of lattice structures, especially oxygen vacancy (vide infra), in agreement with previous reports [34]. 


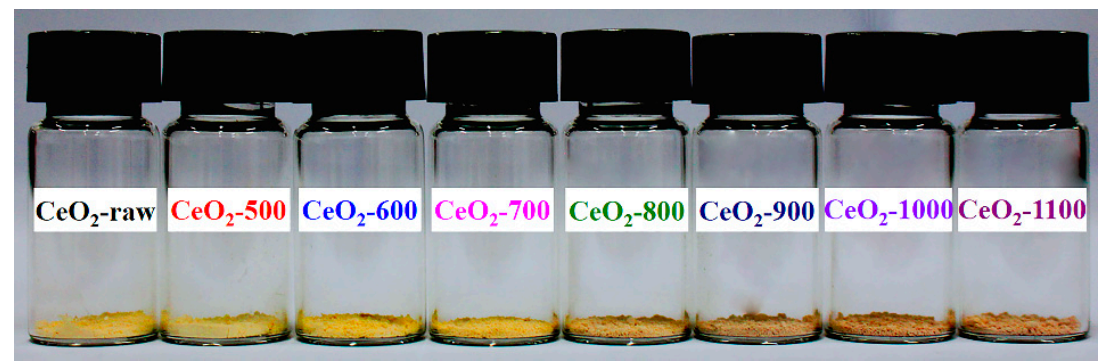

Figure 1. The typical photographs of $\mathrm{CeO}_{2}$-raw and as-prepared $\mathrm{CeO}_{2}$-x catalysts at different calcination temperatures in Ar.

X-ray diffraction (XRD) patterns of $\mathrm{CeO}_{2}$-raw and $\mathrm{CeO}_{2}$-x are displayed in Figure 2. The diffraction peaks corresponding to (111), (200), (220), (311), (222), (400), (331), and (420) planes of cubic ceria with a space group of Fm-3m (JCPDS no.34-0394) were detected, and no peaks from the other ceric and cerous oxide species were manifested in all samples. This implies that the high-temperature calcinations, even as high as $1100^{\circ} \mathrm{C}$, in Ar did not cause phase transformation. The average particle sizes of $\mathrm{CeO}_{2}$-x were affected by the calcination temperature, especially high temperatures. The particle size of $\mathrm{CeO}_{2}-500(18.4 \mathrm{~nm})$, as calculated using the Scherrer equation on the basis of the (111) peak, was close to that of $\mathrm{CeO}_{2}$-raw $(18.0 \mathrm{~nm})$, although $\mathrm{CeO}_{2}-500$ was subjected to the calcination treatment of $500{ }^{\circ} \mathrm{C}$. Subsequently, the particle sizes of $\mathrm{CeO}_{2}-x$ exponentially increased with increasing calcination temperature, that is, particle sizes from $20.7 \mathrm{~nm}$ of $\mathrm{CeO}_{2}-600$ rapidly increased to $29.3 \mathrm{~nm}\left(\mathrm{CeO}_{2}-700\right)$, $48.5 \mathrm{~nm}\left(\mathrm{CeO}_{2}-800\right), 65.9 \mathrm{~nm}\left(\mathrm{CeO}_{2}-900\right), 78.7 \mathrm{~nm}\left(\mathrm{CeO}_{2}-1000\right)$, and $93.2 \mathrm{~nm}\left(\mathrm{CeO}_{2}-1100\right)$.
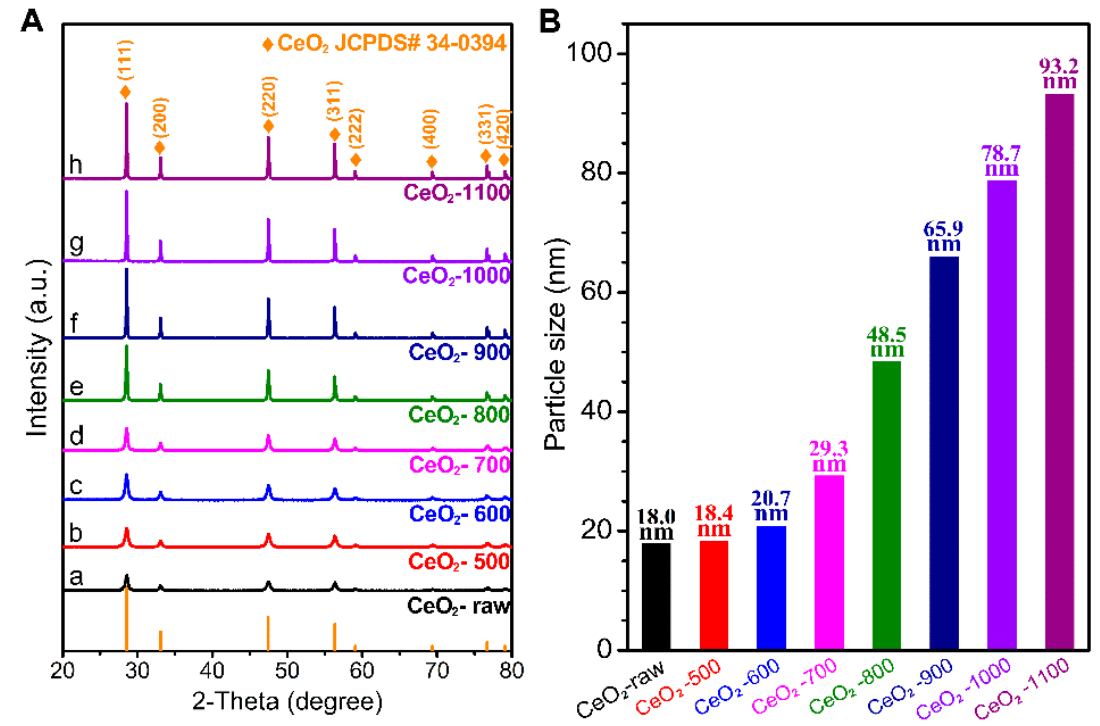

Figure 2. (A) X-ray diffraction (XRD) patterns of $\mathrm{CeO}_{2}$-raw and $\mathrm{CeO}_{2}-\mathrm{x}$; (B) comparison of particle size based on the calculation using the Scherrer equation on the basis of the (111) peak.

According to previous reports [35-38], the total concentrations of oxygen vacancy in $\mathrm{CeO}_{2}$-raw and $\mathrm{CeO}_{2}$-x can be calculated using Equations (6) and (7) (vide infra, see Section 3 for full details). With increasing calcination temperatures, the concentrations of oxygen vacancy of $\mathrm{CeO}_{2}-\mathrm{x}$ slowly increase initially, and then rapidly increase at higher temperatures, as shown in Figure S2 (Supplementary Materials). The oxygen vacancy concentration of $\mathrm{CeO}_{2}-500$ was $0.6 \times 10^{18}$ vacancies $/ \mathrm{cm}^{3}$, only slightly higher than that of $\mathrm{CeO}_{2}$-raw $\left(0.3 \times 10^{18}\right.$ vacancies $\left./ \mathrm{cm}^{3}\right) . \mathrm{CeO}_{2}-600$ had a much larger oxygen vacancy concentration $\left(2.1 \times 10^{18}\right.$ vacancies $\left./ \mathrm{cm}^{3}\right)$. From the catalyst $\mathrm{CeO}_{2}-700\left(6.5 \times 10^{18}\right.$ vacancies $\left./ \mathrm{cm}^{3}\right)$, the oxygen vacancy concentrations of $\mathrm{CeO}_{2}$-x further linearly increased to $13.8 \times 10^{18}$ vacancies $/ \mathrm{cm}^{3}\left(\mathrm{CeO}_{2}-800\right), 19.6 \times 10^{18}$ vacancies $/ \mathrm{cm}^{3}\left(\mathrm{CeO}_{2}-900\right), 26.2 \times 10^{18}$ 
vacancies $/ \mathrm{cm}^{3}\left(\mathrm{CeO}_{2}-1000\right)$, and $32.5 \times 10^{18}$ vacancies $/ \mathrm{cm}^{3}\left(\mathrm{CeO}_{2}-1100\right)$. These results demonstrate that the high-temperature calcinations in Ar facilitated the formation of oxygen vacancies. The high concentrations of oxygen vacancies from the calcination at $800{ }^{\circ} \mathrm{C}$ also led to a darkened yellowish appearance, as recognized previously [39].

The surface electronic states of $\mathrm{CeO}_{2}$-raw and $\mathrm{CeO}_{2}$-x were studied by $\mathrm{X}$-ray photoelectron spectroscopy (XPS), as shown in Figure $3 \mathrm{~A}$. The $\mathrm{Ce} 3 d$ spectrum of $\mathrm{CeO}_{2}$-raw shows the main $\mathrm{Ce} 3 d_{5 / 2}$ and $3 d_{3 / 2}$ core peaks at binding energies of 881.6 and $901.8 \mathrm{eV}$, respectively, indicating the $\mathrm{Ce}^{\mathrm{IV}}$ state in $\mathrm{CeO}_{2}$. Two $\mathrm{CeO}_{2}$ shake-up satellite $3 d_{5 / 2}$ peaks including the $\mathrm{Ce}^{\mathrm{IV}}$ satellite (i) and $\mathrm{Ce}^{\mathrm{IV}}$ satellite (ii) at 889.7 and $897.5 \mathrm{eV}$, respectively, also appeared for $\mathrm{CeO}_{2}$-raw. As for $\mathrm{CeO}_{2}-\mathrm{x}$, in addition to $\mathrm{CeO}_{2}$ peaks, new peaks located at $879.6\left(\mathrm{Ce} 3 d_{5 / 2}\right)$ and $897.7 \mathrm{eV}\left(\mathrm{Ce} 3 d_{3 / 2}\right)$ were the characteristic Ce $\mathrm{e}^{\mathrm{III}}$ peaks, along with the $\mathrm{Ce} \mathrm{e}^{\mathrm{III}}$ satellite $3 d_{5 / 2}$ peak at $886.0 \mathrm{eV}$. However, $\mathrm{XRD}$ characterizations showed only $\mathrm{CeO}_{2}$ phase as the bulk composition in all $\mathrm{CeO}_{2}$-x catalysts, implying that the surface $\mathrm{Ce} \mathrm{e}^{\mathrm{III}}$ oxide layers evidenced by XPS were too thin to be detectable. Variations of the relative intensity ratios of $\mathrm{Ce} \mathrm{e}^{\mathrm{III}} / \mathrm{Ce}^{\mathrm{IV}}$ with respect to $\mathrm{CeO}_{2}$-raw and individual $\mathrm{CeO}_{2}$-x are displayed in Figure 3B. In the lower calcination temperature range from $500{ }^{\circ} \mathrm{C}$ to $800{ }^{\circ} \mathrm{C}$, the $\mathrm{Ce} \mathrm{e}^{\mathrm{III}} / \mathrm{Ce}^{\mathrm{IV}}$ ratios increased relatively quickly from $0.08\left(\mathrm{CeO}_{2}-500\right)$ to $0.33\left(\mathrm{CeO}_{2}-800\right)$. Subsequently, the $\mathrm{Ce} \mathrm{III}^{\mathrm{II}} / \mathrm{Ce}^{\mathrm{IV}}$ ratios continuously increased to $0.5\left(\mathrm{CeO}_{2}-1100\right)$ with a relatively slow rate, implying potential surface/interface configuration inflexion in $\mathrm{CeO}_{2}-800$.
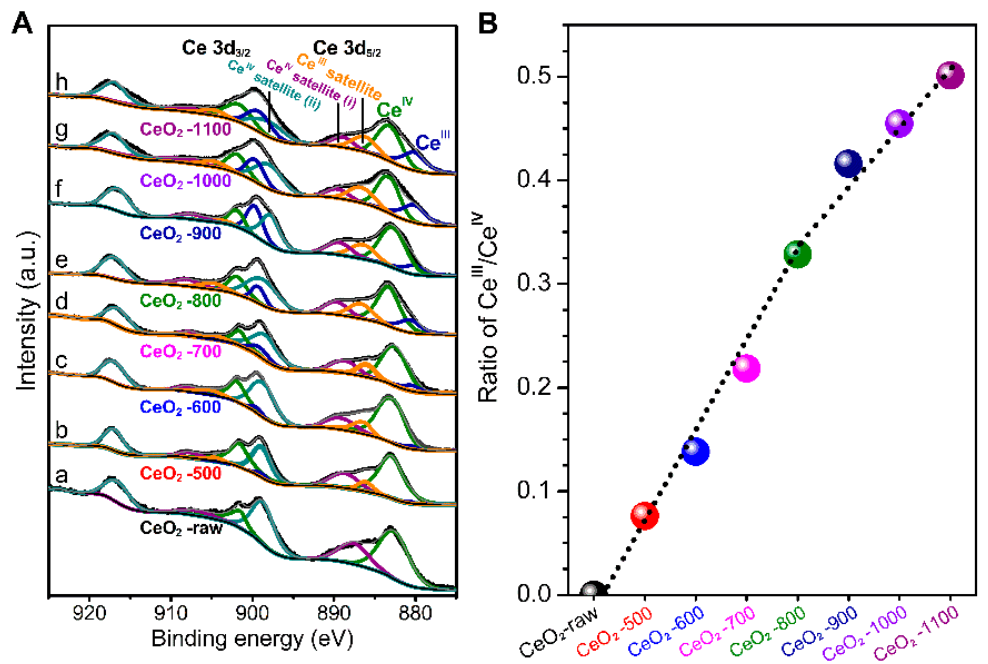

Figure 3. (A) Ce $3 d \mathrm{X}$-ray photoelectron spectroscopy (XPS) spectra, and (B) the relatively intensity ratios of $\mathrm{Ce}^{\mathrm{III}} / \mathrm{Ce}^{\mathrm{IV}}$ of $\mathrm{CeO}_{2}$-raw and $\mathrm{CeO}_{2}$-x.

The absorption edges and band properties for $\mathrm{CeO}_{2}$-raw and $\mathrm{CeO}_{2}$-x were studied using UV-Vis diffuse reflectance spectra (DRS) (Figure 4). One can see that $\mathrm{CeO}_{2}$-raw showed an intense adsorption band from $200 \mathrm{~nm}$ to $380 \mathrm{~nm}$ and a trailing adsorption band until $480 \mathrm{~nm}$. As for $\mathrm{CeO}_{2}-\mathrm{x}$, the intensities of the low-frequency region gradually decreased with increasing calcination temperatures, while the trailing adsorption widths of $\mathrm{CeO}_{2}$-x in the high-frequency region fluctuated to some extent, implying the effective influences of calcination on the band structures of ceria. Tauc plots based on DRS absorption edges show that the band gaps were sharply broadened from $2.97 \mathrm{eV}$ of $\mathrm{CeO}_{2}$-raw to $3.01 \mathrm{eV}\left(\mathrm{CeO}_{2}-500\right), 3.03 \mathrm{eV}\left(\mathrm{CeO}_{2}-600\right), 3.05 \mathrm{eV}\left(\mathrm{CeO}_{2}-700\right), 3.08 \mathrm{eV}\left(\mathrm{CeO}_{2}-800\right), 3.12 \mathrm{eV}\left(\mathrm{CeO}_{2}-900\right)$, $3.15 \mathrm{eV}\left(\mathrm{CeO}_{2}-1000\right)$, and $3.18 \mathrm{eV}\left(\mathrm{CeO}_{2}-1000\right)$ (inset I in Figure 4). The band-gap values increased almost linearly with increasing calcination temperatures (inset II in Figure 4). The oxygen vacancies derived from oxygen atom effusion during the calcination process caused the band gaps to broaden stepwise $[40,41]$, implying the effective influence of calcination on the band-gap structures of ceria. 


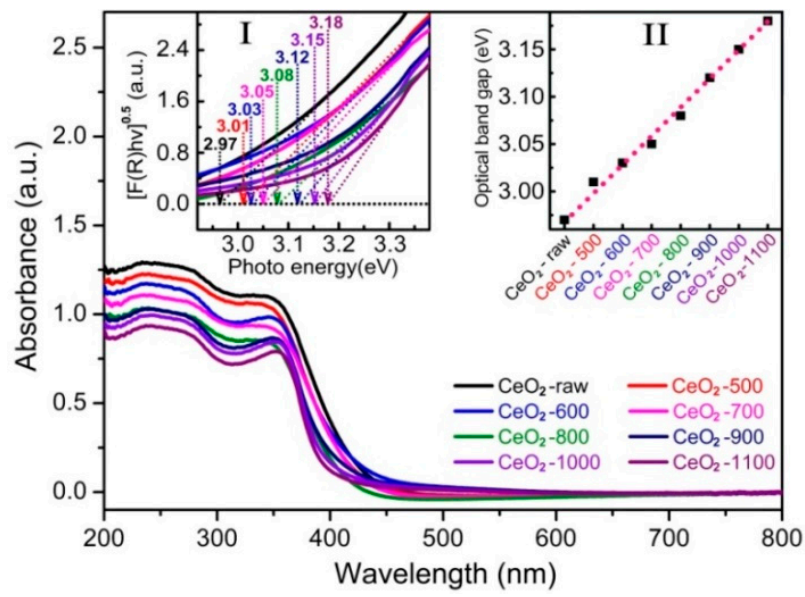

Figure 4. UV-Vis diffuse reflectance spectra (DRS) of $\mathrm{CeO}_{2}$-raw and $\mathrm{CeO}_{2}$-x. Inset I: Tauc plots based on the DRS spectra, where $[F(R) h v]^{0.5}$ is the Kubelka-Munk function for indirect-band semiconductors and $h v$ is photon energy; Inset II: optical band-gap trend.

All $\mathrm{CeO}_{2}$-raw and $\mathrm{CeO}_{2}$-x catalysts exhibited excellent photocurrent response abilities in the light on and off cycles, as demonstrated in Figure 5. Moreover, the photocurrent density of $\mathrm{CeO}_{2}$-raw was about $0.061 \mu \mathrm{A} \cdot \mathrm{cm}^{-2}$ in the first light on stage, before gradually decreasing to $0.041 \mu \mathrm{A} \cdot \mathrm{cm}^{-2}$ in the last light on stage. The photocurrent densities of $\mathrm{CeO}_{2}-\mathrm{x}$ were larger than those of $\mathrm{CeO}_{2}$-raw in all light on stages. Furthermore, the intensities of the photocurrent densities of $\mathrm{CeO}_{2}-\mathrm{x}$ stepwise increased with increasing calcination temperatures. The initial photocurrent densities of $\mathrm{CeO}_{2}-\mathrm{x}$ were $0.085 \mu \mathrm{A} \cdot \mathrm{cm}^{-2}\left(\mathrm{CeO}_{2}-500\right), 0.10 \mu \mathrm{A} \cdot \mathrm{cm}^{-2}\left(\mathrm{CeO}_{2}-600\right), 0.115 \mu \mathrm{A} \cdot \mathrm{cm}^{-2}\left(\mathrm{CeO}_{2}-700\right), 0.120 \mu \mathrm{A} \cdot \mathrm{cm}^{-2}$ $\left(\mathrm{CeO}_{2}-800\right), 0.137 \mu \mathrm{A} \cdot \mathrm{cm}^{-2}\left(\mathrm{CeO}_{2}-900\right), 0.163 \mu \mathrm{A} \cdot \mathrm{cm}^{-2}\left(\mathrm{CeO}_{2}-1000\right)$, and $0.183 \mu \mathrm{A} \cdot \mathrm{cm}^{-2}\left(\mathrm{CeO}_{2}-1100\right)$. $\mathrm{CeO}_{2}-\mathrm{x}$ also showed attenuating photocurrent densities in the following light on stages, and $\mathrm{CeO}_{2}-800$ retained a relatively slow attenuating rate compared to the other $\mathrm{CeO}_{2}$-x catalysts. These results adequately prove that calcination can effectively affect the band structures of ceria, resulting in the promoted photo-response.

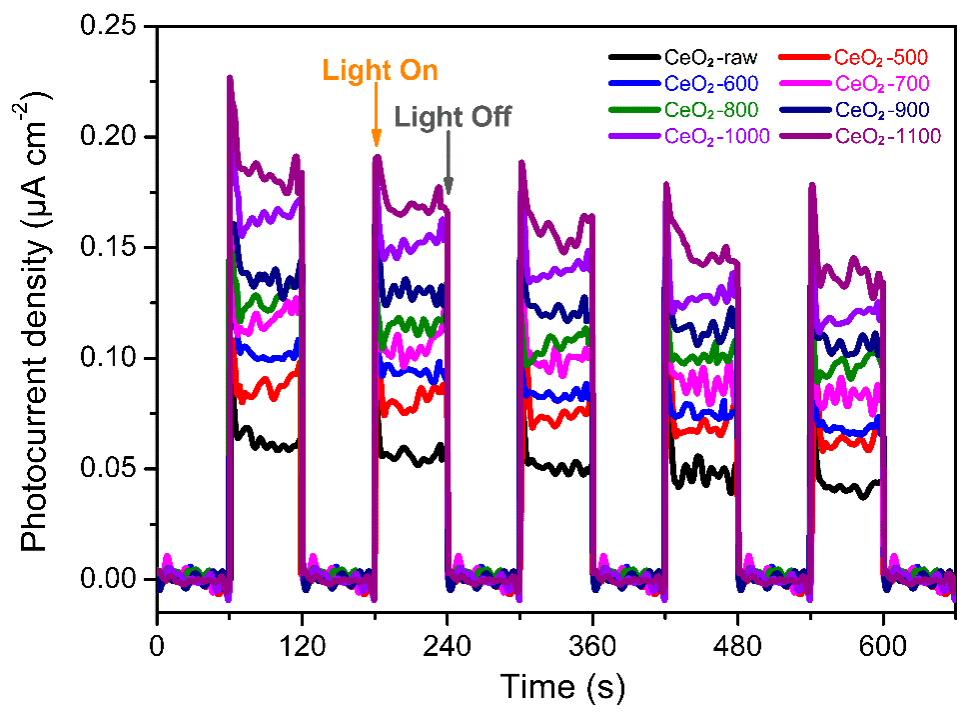

Figure 5. Photocurrent curves of $\mathrm{CeO}_{2}$-raw and $\mathrm{CeO}_{2}$-x catalysts under the simulated solar light (a Xe lamp with an air mass (AM) 1.5 filter) irradiation with a $0-\mathrm{mV}$ bias (vs. $\mathrm{Ag} / \mathrm{AgCl}$ ). The arrows show the light on and light off. 


\subsection{Photocatalytic Conversion of $\mathrm{CH}_{4}$}

Photocatalytic methane oxidation reactions were conducted over $\mathrm{CeO}_{2}$-raw and $\mathrm{CeO}_{2}$-x catalysts stirred/dispersed in pure water under simulated sunlight irradiation. As shown in Figure 6, the aldehyde and ethanol products were reproducibly generated, and no other products were detected over $\mathrm{CeO}_{2}-\mathrm{x}$ catalysts. In contrast, no products were generated over $\mathrm{CeO}_{2}$-raw from $\mathrm{CH}_{4}$ photooxidation. $\mathrm{CeO}_{2}-\mathrm{x}$ produced a small amount of aldehyde with relatively stable production rates of about $1.0 \mu \mathrm{mol} \cdot \mathrm{g}_{\mathrm{cat}}{ }^{-1} \cdot \mathrm{h}^{-1}$ with $\sim 10 \%$ fluctuation. Note that ethanol production rates over $\mathrm{CeO}_{2}-\mathrm{x}$ catalysts quickly increased from $0.9 \mu \mathrm{mol} \cdot \mathrm{g}_{\mathrm{cat}}{ }^{-1} \cdot \mathrm{h}^{-1}\left(\mathrm{CeO}_{2}-500\right)$ to $2.3 \mu \mathrm{mol} \cdot \mathrm{g}_{\mathrm{cat}}{ }^{-1} \cdot \mathrm{h}^{-1}\left(\mathrm{CeO}_{2}-600\right), 4.6 \mu \mathrm{mol} \cdot \mathrm{g}_{\mathrm{cat}}{ }^{-1} \cdot \mathrm{h}^{-1}\left(\mathrm{CeO}_{2}-700\right)$, and $8.5 \mu \mathrm{mol} \cdot \mathrm{g}_{\mathrm{cat}}{ }^{-1} \cdot \mathrm{h}^{-1}\left(\mathrm{CeO}_{2}-800\right)$ initially, and then further increased to $9.4 \mu \mathrm{mol} \cdot \mathrm{g}_{\mathrm{cat}}{ }^{-1} \cdot \mathrm{h}^{-1}\left(\mathrm{CeO}_{2}-900\right)$, $10.3 \mu \mathrm{mol} \cdot \mathrm{g}_{\mathrm{cat}^{-1}} \cdot \mathrm{h}^{-1}\left(\mathrm{CeO}_{2}-1000\right)$, and $11.4 \mu \mathrm{mol} \cdot \mathrm{g}_{\mathrm{cat}^{-1}} \cdot \mathrm{h}^{-1}\left(\mathrm{CeO}_{2}-1100\right)$ with relatively slow rates at the higher temperature range. Such variations of aldehyde and ethanol production rates over $\mathrm{CeO}_{2}$-x resulted in an asymptotic curve for ethanol selectivity. That is, the ethanol selectivity increased quickly from $50.2 \%\left(\mathrm{CeO}_{2}-500\right)$ to $71.3 \%\left(\mathrm{CeO}_{2}-600\right), 80.9 \%\left(\mathrm{CeO}_{2}-700\right)$, and $88.0 \%\left(\mathrm{CeO}_{2}-800\right)$, and then slowly to $90.4 \%\left(\mathrm{CeO}_{2}-900\right), 90.7 \%\left(\mathrm{CeO}_{2}-1000\right), 91.5 \%\left(\mathrm{CeO}_{2}-1100\right)$. Note that the changes in the ethanol selectivity and production rate were highly similar to those of $\mathrm{Ce} e^{\mathrm{III}} / \mathrm{Ce}^{\mathrm{IV}}$ ratios in $\mathrm{CeO}_{2}-\mathrm{x}$, indicating that the activity of producing ethanol was sensitive to the surface $\mathrm{Ce}{ }^{\mathrm{III}}$ species on the as-prepared ceria. Recently, Murali et al. reported that an optimal CeOx layer in the ceria nanoparticle catalyst was obtained via tuning the molar ratio of $\mathrm{Ce}^{\mathrm{III}}$, exhibiting an enhanced photocatalytic performance $[34,35,37,42]$. The quantum efficiency of ethanol production over the catalyst $\mathrm{CeO}_{2}-1100$ was about $0.3 \%$ (Table S1, Supplementary Materials).

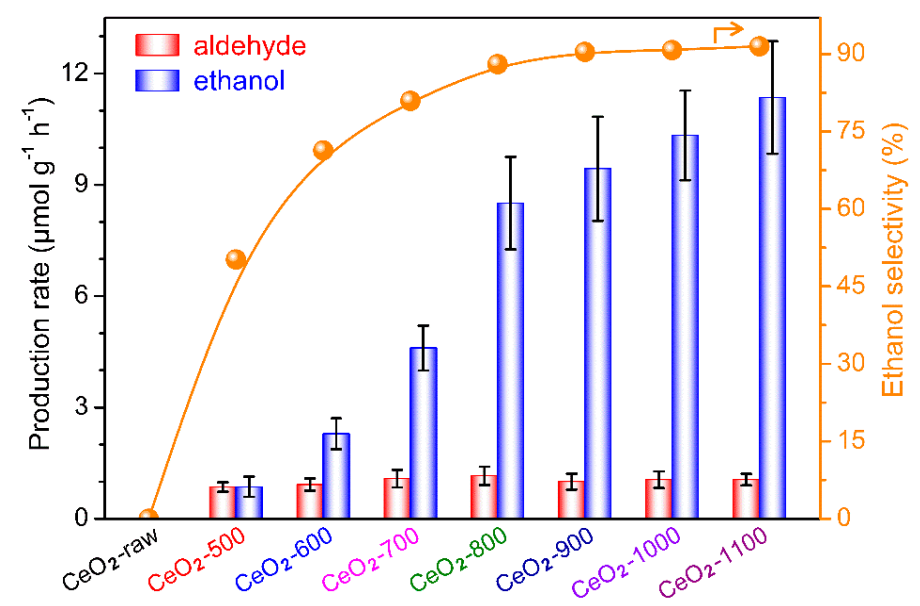

Figure 6. Production rates of the photocatalytic products aldehyde $\left(\mathrm{CH}_{3} \mathrm{CHO}\right)$ and ethanol $\left(\mathrm{CH}_{3} \mathrm{CH}_{2} \mathrm{OH}\right)$ over $\mathrm{CeO}_{2}$-raw and $\mathrm{CeO}_{2}$-x photocatalysts under simulated sunlight irradiation. The ethanol selectivity is shown with orange dots.

Based on the results and discussion above, we propose a hypothetic radical mechanism for photocatalytic $\mathrm{CH}_{4}$ conversion over $\mathrm{CeO}_{2}$-x catalysts according to previous reports $[17,34]$. Oxidative species $\mathrm{O}^{2-}$ and/or hydroxyl radicals (.OH) are firstly formed on the surface of $\mathrm{CeO}_{2}$-x catalysts, which are derived from the interaction between water and holes induced by active oxygen vacancies under simulated solar light irradiation. These $\cdot \mathrm{OH}$ radicals interact with $\mathrm{CH}_{4}$ to produce methyl radicals $\left(\cdot \mathrm{CH}_{3}\right.$ ) (Equation (1)), and then some of the as-formed $\cdot \mathrm{CH}_{3}$ undergoes radical coupling to generate ethane (Equation (2)), which is further attacked by $\cdot \mathrm{OH}$ to produce ethyl radicals $\left(\cdot \mathrm{CH}_{2} \mathrm{CH}_{3}\right)$ (Equation (3)). Ethanol is produced from the reaction between $\cdot \mathrm{CH}_{2} \mathrm{CH}_{3}$ and $\mathrm{H}_{2} \mathrm{O}$ (Equation (4)), while the reaction between hydrogen radicals $(\cdot \mathrm{H})$ and $\cdot \mathrm{OH}$ to produce water (Equation (5)) is a chain termination reaction.

$$
\begin{gathered}
\mathrm{CH}_{4}+\cdot \mathrm{OH} \rightarrow \cdot \mathrm{CH}_{3}+\mathrm{H}_{2} \mathrm{O} . \\
\cdot \mathrm{CH}_{3}+\mathrm{CH}_{3} \rightarrow \mathrm{C}_{2} \mathrm{H}_{6} .
\end{gathered}
$$




$$
\begin{gathered}
\mathrm{C}_{2} \mathrm{H}_{6}+\cdot \mathrm{OH} \rightarrow \cdot \mathrm{CH}_{2} \mathrm{CH}_{3}+\mathrm{H}_{2} \mathrm{O} . \\
\cdot \mathrm{CH}_{2} \mathrm{CH}_{3}+\mathrm{H}_{2} \mathrm{O} \rightarrow \mathrm{C}_{2} \mathrm{H}_{5} \mathrm{OH}+\cdot \cdot \cdot . \\
\cdot \mathrm{H}+\cdot \mathrm{OH} \rightarrow \mathrm{H}_{2} \mathrm{O} .
\end{gathered}
$$

Furthermore, it was demonstrated that the formation of aldehyde is attributed to the oxidation of the product ethanol under the photocatalytic conditions via additional experiments of photocatalytic ethanol conversion. As shown in Figure S3 (Supplementary Materials), the initial ethanol concentrations were $1.03,1.54,2.57$, and $3.86 \mu \mathrm{mol} \cdot \mathrm{L}^{-1}$ in Test 1 , Test 2 , Test 3 , and Test 4 , respectively. After simulated solar light irradiation for $2 \mathrm{~h}$ with Ar flow instead of methane flow, the post-reaction liquid products were found to be aldehyde and unreacted ethanol. Moreover, the amount of aldehyde in different tests remained almost constant $\left(0.23 \mu \mathrm{mol} \cdot \mathrm{L}^{-1}\right)$. Note that the sums of the unreacted ethanol and as-generated aldehyde were equal to the initial ethanol in the individual test. This implies that certain amount of the product ethanol was converted to the equivalent aldehyde under the $\mathrm{CH}_{4}$ photocatalytic conditions. That is, the oxidative species also led to the occurrence of an ethanol oxidation side reaction, resulting in a nearly constant amount of aldehyde in the $\mathrm{CH}_{4}$ photocatalytic conversion process. The cycling performance tests showed that the production rates of aldehyde over $\mathrm{CeO}_{2}-1100$ remained constant (maintaining at $1.1 \mu \mathrm{mol} \cdot \mathrm{g}_{\mathrm{cat}}{ }^{-1} \cdot \mathrm{h}^{-1}$ ) at different cycles (Figure S4, Supplementary Materials). The ethanol production rates were relatively stable with only about $6 \%$ stepwise decay from Cycle 1 to Cycle 3, but they decreased rapidly at Cycle 4 with about 20\% decay. In addition, the catalyst $\mathrm{CeO}_{2}-1100$ showed comparable photocatalytic activities with the best photocatalysts under mild reaction conditions (Table S2, Supplementary Materials).

\section{Materials and Methods}

\subsection{Preparation of Catalysts}

In this work, a calcination method in Ar atmosphere was adopted, and the details were as follows: commercial $\mathrm{CeO}_{2}$ samples (about $0.1 \mathrm{~g}$ ) were put in a U-type quartz tube and purged with $\mathrm{Ar}(99.999 \%$, $200 \mathrm{~mL} \cdot \mathrm{min}^{-1}$ ) for $30 \mathrm{~min}$ before heating. Then, the samples were calcined in flowing Ar at a heating rate of $5^{\circ} \mathrm{C} \cdot \mathrm{min}^{-1}$ to target temperatures $\left(500{ }^{\circ} \mathrm{C}, 600{ }^{\circ} \mathrm{C}, 700{ }^{\circ} \mathrm{C}, 800{ }^{\circ} \mathrm{C}, 900{ }^{\circ} \mathrm{C}, 1000{ }^{\circ} \mathrm{C}\right.$, and $1100{ }^{\circ} \mathrm{C}$ ) and held at the individual target temperatures for $4 \mathrm{~h}$. After cooling down to room temperature in $\mathrm{Ar}$ flow, the as-obtained catalysts were stored in airtight glass bottles.

\subsection{Physical Characterizations}

The crystal structures of the catalysts were determined by X-ray diffraction (XRD) patterns performed on an X-ray diffractometer (Ultima IV, Rigaku Corporation, Tokyo, Japan) employing Cu K $\alpha$ radiation $(\lambda=1.54056 \AA)$ at $40 \mathrm{kV}$ and $40 \mathrm{~mA}$. XRD patterns were recorded at a scan rate of $5^{\circ} \cdot \mathrm{min}^{-1}$ and in the range of $20^{\circ}-80^{\circ}$. The concentrations of oxygen vacancy were calculated using Equations (6) and (7).

$$
\begin{gathered}
\frac{\sqrt{3}}{4}\left(a-a_{0}\right)=c\left[r_{C e^{3+}}-r_{C e^{4+}}+\frac{1}{4}\left(r_{V_{0}}-r_{O^{2-}}\right)\right], \\
V_{0}=2 c,
\end{gathered}
$$

where $a$ is the lattice constant based on the full width half maximum (FWHM) of the (111) diffraction peak of individual samples, and the $a$ values for $\mathrm{CeO}_{2}$-x were $0.5411 \mathrm{~nm}\left(\mathrm{CeO}_{2}\right.$-raw), $0.54112 \mathrm{~nm}\left(\mathrm{CeO}_{2}-500\right)$, $0.54115 \mathrm{~nm}\left(\mathrm{CeO}_{2}-600\right), 0.54126 \mathrm{~nm}\left(\mathrm{CeO}_{2}-700\right), 0.54145 \mathrm{~nm}\left(\mathrm{CeO}_{2}-800\right), 0.5416 \mathrm{~nm}\left(\mathrm{CeO}_{2}-900\right)$, $0.54177 \mathrm{~nm}\left(\mathrm{CeO}_{2}-1000\right)$, and $0.54192 \mathrm{~nm}\left(\mathrm{CeO}_{2}-1100\right) ; a_{0}$ is the lattice parameter $(0.5411 \mathrm{~nm})$ of $\mathrm{CeO}_{2}$ (JCPDS no.34-0394), $\mathrm{c}$ is the coefficient of vacancy concentration, $r_{\mathrm{Ce}^{3+}}$ and $r_{\mathrm{Ce}^{4+}}$ are the radii of $\mathrm{Ce}^{3+}$ and $\mathrm{Ce}^{4+}$, respectively $\left(r_{\mathrm{Ce}^{3+}}=0.1283 \mathrm{~nm}, r_{\mathrm{Ce}^{4+}}=0.1098 \mathrm{~nm}\right), r_{V_{0}}$ and $r_{\mathrm{O}^{2-}}$ are the radii of oxygen vacancy and $\mathrm{O}^{2-}$, respectively $\left(r_{V_{0}}=0.138 \mathrm{~nm}, r_{O^{2-}}=0.124 \mathrm{~nm}\right)$, and $V_{0}$ is the oxygen vacancy concentration. UV-visible absorption spectra were recorded on a UV-visible spectrophotometer 
(UV-2700, Shimadzu Co., Ltd., Kyoto, Japan). XPS spectra were obtained using an X-ray photoelectron spectrometer (Quantum 2000 Scanning ESCA Microprobe instrument, Thermo Fisher Scientific Inc., Waltham, MA., USA) with a monochromatic excitation source of $\mathrm{Al} \mathrm{K} \alpha$ radiation $(h v=1486.6 \mathrm{eV})$ performed under $12 \mathrm{kV}$ and $4 \mathrm{~mA}$. The binding energies in all XPS spectra were calibrated according to the $\mathrm{C} 1 \mathrm{~s}$ peak $(284.8 \mathrm{eV})$. The XPS spectra were deconvolved using a commercially available data-fitting program (Advantage 5.967 software (2016), Thermo Fisher Scientific Inc., Waltham, MA, USA) after a Shirley background subtraction procedure. The photocurrent response tests of the catalysts were carried out on an electrochemical workstation (VMP3, Bio-Logic Inc., Seyssinet-Pariset, France) using the chronoamperometry method at a fixed potential of $0 \mathrm{mV} v$ s. $\mathrm{Ag} / \mathrm{AgCl}$ under chopped illumination periods of $60 \mathrm{~s}$. The catalysts coated on the carbon paper pieces $(2 \mathrm{~cm} \times 2 \mathrm{~cm})$ were used as the working electrode, a Pt wire was used as the counter-electrode, and $\mathrm{KCl}$-saturated $\mathrm{Ag} / \mathrm{AgCl}$ was used as the reference electrode. The $\mathrm{CH}_{4}$-saturated $0.1 \mathrm{M} \mathrm{NaOH}$ aqueous solution was used as the electrolyte solution.

\subsection{Photocatalytic Activity Tests}

In a typical photocatalytic $\mathrm{CH}_{4}$ oxidation reaction, the catalyst $(2 \mathrm{mg}$ ) was suspended in ultra-pure water $(15 \mathrm{~mL})$ with continuous magnetic stirring in a gas-tight glass cell equipped with a constant temperature circulator $\left(25^{\circ} \mathrm{C}\right)$. The set-up of the $\mathrm{CH}_{4}$ photocatalytic conversion is shown in Figure $\mathrm{S} 5$ (Supplementary Materials), and the glass cell with a volume of $20 \mathrm{~mL}$ was covered with a quartz window (effective irradiation diameter of $5 \mathrm{~cm}$ ). The pure $\mathrm{CH}_{4}(99.999 \%)$ was delivered into the cell at a constant rate of $4 \mathrm{~mL} \cdot \mathrm{min}^{-1}$ and was allowed to purge for $30 \mathrm{~min}$ prior to the beginning of experiments. The pressure of the reaction cell remained at 0.2 bar. A 300-W Xe lamp (CEL-HXF300, Beijing CeAuLight Co., Ltd., Beijing, China) with an air mass (AM 1.5 filter, $100 \mathrm{~mW} \cdot \mathrm{cm}^{-2}$ ) was used as the simulated light source, which possessed a similar solar spectrum (Figure S6, Supplementary Materials). In the methane photocatalytic conversion, there were two kinds of products, i.e., one in the gas phase, and the other in the liquid phase. The gas-phase products were measured by the on-line GC (GC-2014, Shimadzu Co., Ltd., Kyoto, Japan) equipped with a Molecular sieve-13X 60/80 column and a Plot-Q80/100 column using the flame ionization detector (FID). The amount of the possible gas-phase products was too little to be detected by the on-line GC, resulting in no gas-phase product detected in all $\mathrm{CH}_{4}$ photocatalytic oxidation tests. On the other hand, products such as ethanol and aldehyde were dissolved in the suspension, which could not be detected by the on-line GC. Instead, these liquid-phase products were detected by the off-line GC. In brief, after filtration of the suspending particles (using an injector with the $0.02-\mu \mathrm{m}$ polytetrafluoroethylene (PTFE) membrane), liquid products from each photocatalytic experiment for $2 \mathrm{~h}$ were analyzed using the off-line GC-2014 (Shimadzu) equipped with an autosampler and an OVI-G43 capillary column (Supelco ${ }^{\circledR}$, Sigma-Aldrich Inc., St. Louis, MO, USA). The production rates of liquid products were calculated as follows:

$$
\text { Production rate }=\frac{C_{\text {product }} \times V \times \rho_{\text {product }}}{M_{\text {product }} \times m_{\text {catalyst }} \times t^{\prime}}
$$

where $C_{\text {product }}(\mathrm{ppm})$ is the concentration of the product (aldehyde or ethanol), $V$ is the liquid volume $(15 \mathrm{~mL}), \rho_{\text {product }}$ is the density of the products aldehyde $\left(0.7834 \mathrm{~g} \cdot \mathrm{cm}^{-3}\right)$ or ethanol $\left(0.7893 \mathrm{~g} \cdot \mathrm{cm}^{-3}\right)$, $M_{\text {product }}$ is the molar mass of aldehyde $\left(44 \mathrm{~g} \cdot \mathrm{mol}^{-1}\right)$ or ethanol $\left(46.03 \mathrm{~g} \cdot \mathrm{mol}^{-1}\right)$, and $t$ is the reaction time (2 h). Control experiments including no photocatalysts or no light irradiation were carried out, and no products were detected.

Furthermore, additional experiments for investigating aldehyde origin were conducted with ethanol as an initial reactant in water under the same photocatalytic reaction conditions except for replacing methane with Ar. Briefly, the catalyst $(2 \mathrm{mg})$ and specific amounts of ethanol with concentrations of $1.03,1.54,2.57$, and $3.86 \mu \mathrm{mol} \cdot \mathrm{L}^{-1}$ were added to ultra-pure water $(15 \mathrm{~mL})$ with continuous magnetic stirring in the cell. The Ar flow $\left(4 \mathrm{~mL} \cdot \mathrm{min}^{-1}\right)$ was delivered into the cell, and light 
irradiation was applied to the cell for $2 \mathrm{~h}$ after Ar purging for $30 \mathrm{~min}$. The post-reaction liquid products were analyzed after filtration by the off-line GC.

\section{Conclusions}

In summary, we presented an effective approach for the selective conversion of methane to C2 products ethanol and aldehyde in ambient conditions and simulated solar light irradiation. Commercially available ceria nanoparticles that behave inertly for methane photocatalytic conversion were evoked and became active after modification with oxygen vacancies via calcination at high temperatures in Ar atmosphere. Higher temperatures led to quickly growing particle sizes with abundant oxygen vacancies, as well as higher ratios of $\mathrm{Ce}{ }^{\mathrm{III}} / \mathrm{Ce}^{\mathrm{IV}}$, resulting in higher activities for methane conversion. The production of ethanol was found to be more sensitive to the surface Ce $\mathrm{C}^{\mathrm{III}}$ species on as-prepared ceria. The aldehyde formation can be attributed to the oxidation of the product ethanol. The present study provides an effective approach to create oxygen vacancies and surface Ce $\mathrm{e}^{\mathrm{III}}$ species in commercial ceria for evoking methane photocatalytic conversion to $\mathrm{C} 2$ oxygenates.

Supplementary Materials: The following are available online at http://www.mdpi.com/2073-4344/10/2/196/s1: Figure S1: (A) Oxygen signal $(\mathrm{m} / \mathrm{z}=32)$ of mass spectrometry in Ar flow ( $20 \mathrm{~mL} / \mathrm{min})$, and (B) TG curves during the temperature-programmed calcinations of commercial $\mathrm{CeO}_{2}$ nanoparticles at a heating rate of $5{ }^{\circ} \mathrm{C} \cdot \mathrm{min}^{-1}$ in air and $\mathrm{Ar}$ flow $(20 \mathrm{~mL} / \mathrm{min})$, respectively; Figure S2: Concentrations of oxygen vacancies of $\mathrm{CeO}_{2}-\mathrm{raw}$ and $\mathrm{CeO}_{2}-\mathrm{x}$; Figure S3: Photocatalytic ethanol conversion to aldehyde over $\mathrm{CeO}_{2}-1100$ under simulated sunlight irradiation in pure water. Initial ethanol concentrations were $1.03,1.54,2.57$, and $3.86 \mu \mathrm{mol} \cdot \mathrm{L}^{-1}$ in the experiments Test1, Test2, Test3, and Test4, respectively; Figure S4: Cycling performances of $\mathrm{CH}_{4}$ photocatalytic conversion over $\mathrm{CeO}_{2}-1100$; Figure S5: The photographs of (A) the methane photocatalytic conversion set-up and (B) the gas-tight glass cell; Table S1: Calculation of quantum efficiency of ethanol production over the catalyst $\mathrm{CeO}_{2}-1100$; Table S2: Comparison of the photocatalytic activities.

Author Contributions: W.C. conceptualized and designed the study. J.D. prepared catalysts and performed the reactions and most of characterizations. G.W. conducted additional tests. J.D., W.C., Y.S., X.D., G.L., J.F., W.W., and Y.S. contributed data analysis and wrote the paper. All authors read and agreed to the published version of the manuscript.

Funding: This reseach was funded by the National Natural Science Foundation of China (Nos. 91745114, 21802160), the Ministry of Science and Technology of China (Nos. 2016YFA0202800, 2018YFB0604700), the Shanghai Sailing Program (No. 18YF1425700), and the Shanghai Advanced Research Institute Innovation Research Program (Nos. Y756812ZZ1 (172002) and Y756803ZZ1 (171003)).

Acknowledgments: We appreciate the facility supports from the Shanghai Functional Platform for Innovation Low Carbon Technology. W.C. also acknowledges the support from the Hundred Talents Program of the Chinese Academy of Sciences.

Conflicts of Interest: The authors declare no conflicts of interest.

\section{References}

1. Yuliati, L.; Yoshida, H. Photocatalytic conversion of methane. Chem. Soc. Rev. 2008, 37, 1592-1602. [CrossRef] [PubMed]

2. Gunsalus, N.J.; Koppaka, A.; Park, S.H.; Bischof, S.M.; Hashiguchi, B.G.; Periana, R.A. Homogeneous functionalization of methane. Chem. Rev. 2017, 117, 8521-8573. [CrossRef]

3. Xie, S.; Lin, S.; Zhang, Q.; Tian, Z.; Wang, Y. Selective electrocatalytic conversion of methane to fuels and chemicals. J. Energy Chem. 2018, 27, 1629-1636. [CrossRef]

4. Schwach, P.; Pan, X.; Bao, X. Direct conversion of methane to value-added chemicals over heterogeneous catalysts: Challenges and prospects. Chem. Rev. 2017, 117, 8497-8520. [CrossRef]

5. Tang, P.; Zhu, Q.; Wu, Z.; Ma, D. Methane activation: The past and future. Energy Environ. Sci. 2014, 7, 2580-2591. [CrossRef]

6. Paunović, V.; Zichittella, G.; Moser, M.; Amrute, A.P.; Pérez-Ramírez, J. Catalyst design for natural-gas upgrading through oxybromination chemistry. Nat. Chem. 2016, 8, 803-809. [CrossRef] [PubMed]

7. Lee, K.J.; Dempsey, J.L. When electrochemistry met methane: Rapid catalyst oxidation fuels hydrocarbon functionalization. ACS Cent. Sci. 2017, 3, 1137-1139. [CrossRef] [PubMed] 
8. Nikolla, E.; Schwank, J.W.; Linic, S. Hydrocarbon steam reforming on Ni alloys at solid oxide fuel cell operating conditions. Catal. Today 2008, 136, 243-248. [CrossRef]

9. Wang, B.; Albarracín-Suazo, S.; Pagán-Torres, Y.; Nikolla, E. Advances in methane conversion processes. Catal. Today 2017, 285, 147-158. [CrossRef]

10. Enger, B.C.; Lødeng, R.; Holmen, A. A review of catalytic partial oxidation of methane to synthesis gas with emphasis on reaction mechanisms over transition metal catalysts. Appl. Catal. A Gen. 2008, 346, 1-27. [CrossRef]

11. Olivos-Suarez, A.I.; Szécsényi, A.; Hensen, E.J.; Ruiz-Martinez, J.; Pidko, E.A.; Gascon, J. Strategies for the direct catalytic valorization of methane using heterogeneous catalysis: Challenges and opportunities. ACS Catal. 2016, 6, 2965-2981. [CrossRef]

12. Karakaya, C.; Kee, R.J. Progress in the direct catalytic conversion of methane to fuels and chemicals. Prog. Energy Combust. Sci. 2016, 55, 60-97. [CrossRef]

13. Mesters, C. A selection of recent advances in C1 chemistry. Annu. Rev. Chem. Biomol. Eng 2016, 7, $223-238$. [CrossRef]

14. Song, J.; Sun, Y.; Ba, R.; Huang, S.; Zhao, Y.; Zhang, J.; Zhu, Y. Monodisperse Sr- $\mathrm{La}_{2} \mathrm{O}_{3}$ hybrid nanofibers for oxidative coupling of methane to synthesize $C_{2}$ hydrocarbons. Nanoscale 2015, 7, 2260-2264. [CrossRef] [PubMed]

15. Guo, X.; Fang, G.; Li, G.; Ma, H.; Fan, H.; Yu, L.; Tan, D. Direct, nonoxidative conversion of methane to ethylene, aromatics, and hydrogen. Science 2014, 344, 616-619. [CrossRef]

16. Soulivong, D.; Norsic, S.; Taoufik, M.; Coperet, C.; Thivolle-Cazat, J.; Chakka, S.; Basset, J.M. Non-Oxidative Coupling Reaction of Methane to Ethane and Hydrogen Catalyzed by the Silica-Supported Tantalum Hydride: $(\equiv \mathrm{SiO})_{2} \mathrm{Ta}-\mathrm{H}$. J. Am. Chem. Soc. 2008, 130, 5044-5045. [CrossRef]

17. Murcia-López, S.; Villa, K.; Andreu, T.; Morante, J.R. Partial oxidation of methane to methanol using bismuth-based photocatalysts. ACS Catal. 2014, 4, 3013-3019. [CrossRef]

18. Chen, X.; Li, Y.; Pan, X.; Cortie, D.; Huang, X.; Yi, Z. Photocatalytic oxidation of methane over silver decorated zinc oxide nanocatalysts. Nat. Commun. 2016, 7, 12273. [CrossRef] [PubMed]

19. Xie, J.; Jin, R.; Li, A.; Bi, Y.; Ruan, Q.; Deng, Y.; Zhang, Y.; Yao, S.; Sankar, G.; Ma, D.; et al. Highly selective oxidation of methane to methanol at ambient conditions by titanium dioxide-supported iron species. Nat. Catal. 2018, 1, 889-896. [CrossRef]

20. Zhou, Y.; Zhang, L.; Wang, W. Direct functionalization of methane into ethanol over copper modified polymeric carbon nitride via photocatalysis. Nat. Commun. 2019, 10, 506. [CrossRef]

21. Ji, P.; Zhang, J.; Chen, F.; Anpo, M. Study of Adsorption and Degradation of Acid Orange 7 on the Surface of $\mathrm{CeO}_{2}$ under Visible Light Irradiation. Appl. Catal. B 2009, 85, 148-154. [CrossRef]

22. Feng, T.; Wang, X.; Feng, G. Synthesis of Novel $\mathrm{CeO}_{2}$ Microspheres with Enhanced Solar Light Photocatalyic Properties. Mater. Lett. 2013, 100, 36-39. [CrossRef]

23. Chen, F.; Cao, Y.; Jia, D. Preparation and Photocatalytic Property of $\mathrm{CeO}_{2}$ Lamellar. Appl. Surf. Sci. 2011, 257, 9226-9231. [CrossRef]

24. Sabari Arul, N.; Mangalaraj, D.; Kim, T.W.; Chen, P.C.; Ponpandian, N.; Meena, P.; Masuda, Y. Synthesis of $\mathrm{CeO}_{2}$ Nanorods with Improved Photocatalytic Activity: Comparison between Precipitation and Hydrothermal Process. J. Mater. Sci. Mater. Electron. 2013, 24, 1644-1650. [CrossRef]

25. Chan, S.H.S.; Yeong Wu, T.; Juan, J.C.; Teh, C.Y. Recent Developments of Metal Oxide Semiconductors as Photocatalysts in Advanced Oxidation Processes (AOPs) for Treatment of Dye Waste-Water. J. Chem. Technol. Biotechnol. 2011, 86, 1130-1158. [CrossRef]

26. Bamwenda, G.R.; Arakawa, H. Cerium Dioxide as a Photocatalyst for Water Decomposition to $\mathrm{O}_{2}$ in the Presence of $\mathrm{Ce}_{\mathrm{aq}}{ }^{4+}$ and $\mathrm{Fe}_{\mathrm{aq}}{ }^{3+}$ Species. J. Mol. Catal. A Chem. 2000, 161, 105-113. [CrossRef]

27. Bamwenda, G.R.; Uesigi, T.; Abe, Y.; Sayama, K.; Arakawa, H. The Photocatalytic Oxidation of Water to $\mathrm{O}_{2}$ over Pure $\mathrm{CeO}_{2}, \mathrm{WO}_{3}$ and $\mathrm{TiO}_{2} \mathrm{Using} \mathrm{Fe}^{3+}$ and $\mathrm{Ce}^{4+}$ as Electron Acceptors. Appl. Catal. A 2001, 205, 117-128. [CrossRef]

28. Primo, A.; Marino, T.; Corma, A.; Molinari, R.; García, H. Efficient Visible-Light Photocatalytic Water Splitting by Minute Amounts of Gold Supported on Nanoparticulate $\mathrm{CeO}_{2}$ Obtained by a Biopolymer Templating Method. J. Am. Chem. Soc. 2011, 133, 6930-6933. [CrossRef]

29. Abanades, S.; Flamant, G. Thermochemical hydrogen production from a two-step solar-driven water-splitting cycle based on cerium oxides. Sol. Energy 2006, 80, 1611-1623. [CrossRef] 
30. Meiqing, S.; Xinquan, W.; Yuan, A.; Duan, W.; Minwei, Z.; Jun, W. Dynamic Oxygen Storage Capacity Measurements on Ceria-Based Material. J. Rare Earths 2007, 25, 48-52. [CrossRef]

31. Melchionna, M.; Fornasiero, P. The role of ceria-based nanostructured materials in energy applications. Mater. Today 2014, 17, 349-357. [CrossRef]

32. Karran Woan, Y.-Y.T.W.S. Synthesis and characterization of luminescent cerium oxide nanoparticles. Nanomedicine 2010, 5, 233-242.

33. Muduli, S.K.; Wang, S.; Chen, S.; Ng, C.F.; Huan, C.H.A.; Sum, T.C.; Soo, H.S. Mesoporous cerium oxide nanospheres for the visible-light driven photocatalytic degradation of dyes. Beilstein J. Nanotechnol. 2014, 5, 517-523. [CrossRef] [PubMed]

34. Choudhury, B.; Chetri, P.; Choudhury, A. Oxygen defects and formation of $\mathrm{Ce}^{3+}$ affecting the photocatalytic performance of $\mathrm{CeO}_{2}$ nanoparticles. RSC Adv. 2014, 4, 4663-4671. [CrossRef]

35. Gao, H.; Yang, H.; Yang, G.; Wang, S. Effects of oxygen vacancy and sintering temperature on the photoluminescence properties and photocatalytic activity of $\mathrm{CeO}_{2}$ nanoparticles with high uniformity. Mater. Technol. 2018, 33, 321-332. [CrossRef]

36. Zhou, X.D.; Huebner, W. Size-induced lattice relaxation in $\mathrm{CeO}_{2}$ nanoparticles. Appl. Phys. Lett. 2001, 79, 3512-3514. [CrossRef]

37. Choudhury, B.; Choudhury, A. $\mathrm{Ce}^{3+}$ and oxygen vacancy mediated tuning of structural and optical properties of $\mathrm{CeO}_{2}$ nanoparticles. Mater. Chem. Phys. 2012, 131, 666-671. [CrossRef]

38. Choudhury, B.; Chetri, P.; Choudhury, A. Annealing temperature and oxygen-vacancy-dependent variation of lattice strain, band gap and luminescence properties of $\mathrm{CeO}_{2}$ nanoparticles. J. Exp. Nanosci. 2015, 10, 103-114. [CrossRef]

39. Mogensen, M.; Sammes, N.M.; Tompsett, G.A. Physical, chemical and electrochemical properties of pure and doped ceria. Solid State Ion. 2000, 129, 63-94. [CrossRef]

40. Goubin, F.; Rocquefelte, X.; Whangbo, M.H.; Montardi, Y.; Brec, R.; Jobic, S. Experimental and theoretical characterization of the optical properties of $\mathrm{CeO}_{2}, \mathrm{SrCeO}_{3}$, and $\mathrm{Sr}_{2} \mathrm{CeO}_{4}$ containing $\mathrm{Ce}^{4+}$ (f0) ions. Chem. Mater. 2004, 16, 662-669. [CrossRef]

41. Shi, S.; Ke, X.; Ouyang, C.; Zhang, H.; Ding, H.; Tang, Y.; Tang, W. First-principles investigation of the bonding, optical and lattice dynamical properties of $\mathrm{CeO}_{2}$. J. Power Sources 2009, 194, 830-834. [CrossRef]

42. Murali, A.; Lan, Y.P.; Sohn, H.Y. Effect of oxygen vacancies in non-stoichiometric ceria on its photocatalytic properties. Nano Struct. Nano Objects 2019, 18, 100257. [CrossRef] 